\title{
Micro-Sized glucose biosensor based on composite pH sensor
} \section{Mikro boyutta pH temelli potansiyometrik glikoz biyosensör}

\author{
Derya BAL ALTUNTAŞ⿻ ${ }^{*}$ (D) Özlem TAVUKÇUOĞLU2 \\ ${ }^{1}$ Bioengineering Department, Engineering Faculty, Recep Tayyip Erdogan University, Rize, Turkey. \\ derya.balaltuntas@erdogan.edu.tr \\ 2 Bioengineering Department, Chemical and Metallurgical Engineering Faculty, Yildiz Technical University, Istanbul, Turkey. \\ ozlemoztolan@gmail.com
}

Received/Geliș Tarihi: 13.10.2017, Accepted/Kabul Tarihi: 02.08.2018

* Corresponding author/Yazișilan Yazar

\begin{abstract}
Today's scientific and technical advances have led to significant advances in biosensor technology, leading to widespread use of biosensors in areas such as food technology, the environment, pharmaceuticals and clinical diagnostics, biochemistry, and analytical chemistry. Improvements in the ion-selective sensor technology used in the preparation of potentiometric biosensors and the increase in the number of sensor materials have also accelerated the development of new types of potentiometric biosensors. Thus, in this study, information is given on the development of a new micro sized potentiometric glucose biosensor based on composite $p H$ sensor. Glucose oxidase was immobilized on the composite layer as the biorecognition element. The surface of glucose biosensor based composite $\mathrm{pH}$ sensing matrices was first examined for electrochemical elucidation by using cyclic voltammetry and electrochemical impedance spectroscopy. The rate of electron transfer resulted in a stable response behavior of the biosensor and made it a suitable potentiometric sensor for detection of glucose. A linear response in concentration range from $5 \times 10^{-5}$ to $1 \times 10^{-1} \mathrm{~mol} / \mathrm{L}$ was obtained with a detection limit of $2 \times 10^{-5} \mathrm{~mol} / \mathrm{L}$ for the potentiometric detection of glucose. The biosensor exhibited a fast response time (10 s), had good stability, and an extended lifetime.
\end{abstract}

Keywords: Solid-state composite sensor, Miniatruization, Diabet follow-up, Glucose biosensor

\section{Introduction}

In general, biosensors are defined as analytical/bioanalytical devices which are developed by combining the selectivity characteristics of chemical and biological molecules and the process capability of modern electronic techniques by making use of a great number of scientific fields such as chemistry, biochemistry, biology and engineering. Electrochemical biosensor systems which are based on specific enzymesubstrate reactions have important features such as being miniaturized, economical, portable and showing high selectivity and sensitivity towards special types. Since the immobilization of biological molecules and the design of transducer sensor membrane interface technology have a significant effect on biosensor performance (linear operating range, selectivity, response time, sensitivity, economic life, stability and sensitivity against interfering agents), they play a key role in electrochemical biosensor systems [1]. In addition, they are important for biosensor production which has a close micro environment not influenced by external environment conditions. Thus, researches in biosensor systems have focused on new immobilized enzyme systems and designs for an effective detection [2],[3]. The aim of this study is to develop a
Öz

Günümüzdeki bilimsel ve teknik ilerlemeler, biyosensör teknolojisinde önemli gelişmelere yol açarak biyosensörlerin gıda teknolojileri, çevre, farmasi ve klinik teşhis, biyokimya, analitik kimya gibi alanlarda yaygın olarak kullanılmasina neden olmuștur. Potansiyometrik biyosensörlerin hazırlanmasında kullanılan iyon-seçici sensör teknolojisindeki gelișmeler ve sensör materyallerin sayılarının artması, yeni tip potansiyometrik biyosensörlerin geliștirilmesini de hızlandırmıștır. Nitekim, bu çalıșmada, kompozit pH sensörüne dayalı yeni bir mikro boyutlu potansiyometrik glikoz biyosensörünün geliștirilmesi ele alınmıștır. Glikoz oksidaz, biyotanıma elemanı olarak kompozit tabaka üzerinde immobilize edildi. Kompozit $p H$ algılama esaslı glikoz biyosensör matriksinin yüzeyi ilk olarak elektrokimyasal tanımlama için dönüșümlü voltametri ve elektrokimyasal impedans spektroskopisi kullanılarak incelendi. Yüksek elektron transfer hızı, biyosensörün kararlı bir tepki davranıșına sahip olduğunu ve glikozun saptanması için uygun bir potansiyometrik sensör olduğunu göstermektedir. Glikozun potansiyometrik tespiti için $2 \times 10^{-5} \mathrm{~mol} / \mathrm{L}$ saptama sınırı ile $5 \times 10^{-5}$ ila $1 \times 10^{-1} \mathrm{~mol} / \mathrm{L}$ konsantrasyon aralı̆ı̆ıda lineer bir cevap elde edildi. Biyosensör hizh bir tepki süresi $(10 \mathrm{~s})$ gösterdi, iyi bir kararlılığa ve uzun bir ömre sahipti.

Anahtar kelimeler: Katı-hal kompozit pH sensör, Minyatürizasyon, Diyabet takibi, Glikoz biyosensör

new type glucose sensitive potentiometric biosensor by using micro size composite $\mathrm{pH}$ sensitive sensor.

\subsection{Potentiometric sensor systems}

In potentiometric sensory systems, the potential difference between the reference electrode and the indicator electrode, which can be considered small, is measured without giving any current to the cell. While reference electrode shows fixed potential, indicator electrode shows a potential which changes according to the activity of the ion it is sensitive to. Potential difference is within logarithmic association of the concentration (eq. 1).

$$
E=E^{0}+R T Z_{i} F \ln a_{i} / a_{\beta}
$$

$E$ : Standard electrode potential,

$a_{i}$ and $a_{\beta}$ : ionic activity,

$R$ : Gas constant,

$T$ : Absolute temperature,

$F$ :Faraday constant,

$Z$ : Ionic charge. 
Ion selective electrode, which selectively measures ionic types, is a potentiometric sensor. Potentiometric sensor generally includes a membrane with a special composition which is solid (like glass) or polymer. Membrane composition in the membrane-solution interface determines membrane's selectivity towards ion.

Figure 1a shows the pattern of a classical ion selective electrode. Such an electrode includes internal reference electrode and internal reference solution. Figure $1 \mathrm{~b}$ shows composite $\mathrm{pH}$ sensor which does not include internal reference electrode and internal reference solution and which allows for preparation in desired size and type. Figure 2 shows a comparative image of composite $\mathrm{pH}$ sensors versus glass $\mathrm{pH}$ electrode.

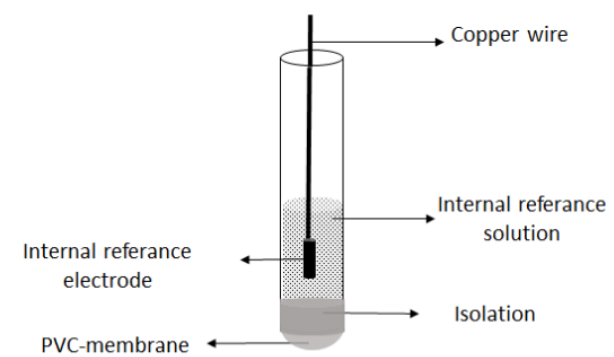

(a)

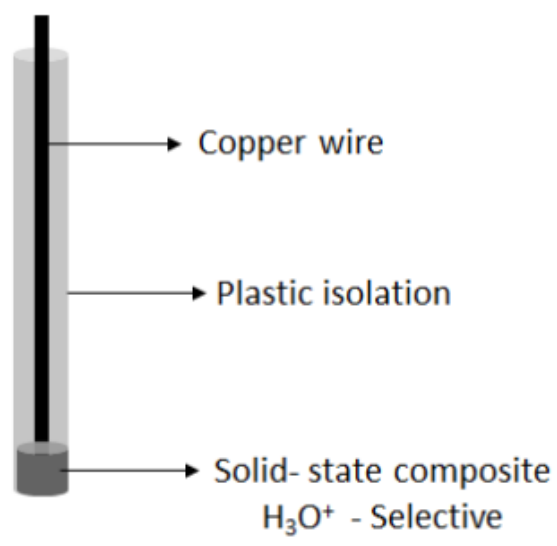

(b)

Figure 1(a): Classical ion selective electrode. (b): Composite $\mathrm{pH}$ sensor.

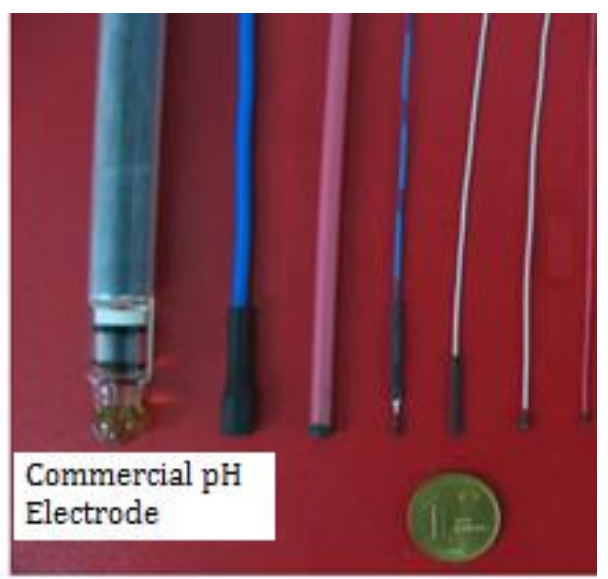

\subsection{Potentiometric biosensors}

The developments in ion-selective sensor technology used in the preparation of potentiometric biosensors and the increase in the number of sensor materials have accelerated the development of new type potentiometric biosensors [4]-[6] Polyvinylchloride (PVC) type membrane electrodes prepared by using suitable ionophore agents have the advantage of developing simple biosensors which show short response time and give repeatable results [7],[8].

In general, enzymes are fixed on a PVC type ion selective electrode membrane surface by using glutaraldehyde crosslinker [9],[10]. However, adherence of the enzyme with crosslinker to the surface of a PVC type ion selective electrode membrane surface with a hydrophobic surface is very weak. Thus, the enzyme has begun to be adhered effectively by using functionalized PVC (aminized or carboxylated) instead of PVC [11]. Potentiometric behaviors of such functional PVC membrane ion selective electrodes have been analyzed in detail [12],[1],[2]. At the same time, it has been discussed whether functional PVC can be used in developing new biosensors $[11],[12]$. On the other hand, in clinical works, it is also very important to develop miniaturized biosensors to minimize enzyme and material use for simple measurement methods [13]. In this regard, the interest in using totally solid-state ion selective membrane sensors has been on the increase recently [14],[15]. These types of sensors are different from those used with classical ones. These sensors are prepared by adhering the membrane cocktail on a solid-state contact (conductive) construction which is a mixture of polymer and modified graphite. At the same time, totally solid-state membrane sensors also allow for the design of biosensors and flowthrough flow cells which are economical and which can be miniaturized easily.

\subsection{Potentiometric Glucose Biosensors}

Glucose oxidase is a glucose-specific enzyme. It catalyzes glucose and releases gluconic acid in the environment as shown in the following reaction eq. 2 and eq. 3 :

$$
\text { Glucose }+\mathrm{O}_{2}+\mathrm{H}_{2} \mathrm{O} \stackrel{\text { GOx }}{\longrightarrow} \text { Gluconolactone }+\mathrm{H}_{2} \mathrm{O}_{2}
$$

$$
\text { Gluconolactone }+\mathrm{H}_{2} \mathrm{O} \rightarrow \text { Gluconic acid }
$$

Gluconic acid, which is the bio-catalytic product of the reaction, changes the $\mathrm{pH}$ of the medium. Hence, this change which occurs on the bio-layer of the sensor and which occurs because of biocatalytic reaction is felt by $\mathrm{pH}$ sensor. Thus, glucose oxidase enzyme should be adhered effectively on the surface or within the $\mathrm{pH}$ sensor membrane. A vast number of potentiometric glucose biosensors which were based on the basis of $\mathrm{pH}$ sensor, have been developed. In all of these biosensors, glucose oxidase has been adhered on glass or conductive polymer electrode surface with cross-linkers. Composite $\mathrm{pH}$ sensor can be adhered on bio-membrane surface or within membrane physically or chemically or in the form of a thin film. Glucosesensitive biosensor, which is prepared like this, measures hydronium ion that emerges because of bio-catalytical reaction $\left(\mathrm{H}_{3} \mathrm{O}^{+}\right)$[13]. The possible structure of glucose biosensor, which was based on composite $\mathrm{pH}$ sensor, given in Figure 3. As can be seen in Figure 3, glucose biosensor, which that has no innerreference solution and inner-reference electrode thus allows for a micro-sized glucose biosensor preparation.

Figure 2: Composite $\mathrm{pH}$ sensors and commercial $\mathrm{pH}$ electrode. 


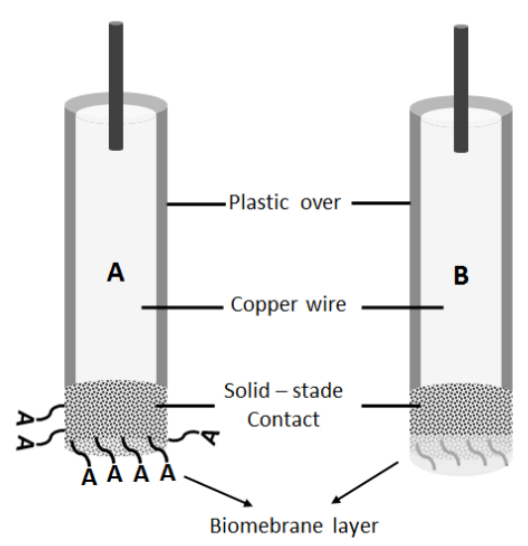

a) Covalend bound

b) Polymer bound

Figure 3: Micro-size potentiometric glucose biosensors

(a): Covalent bound (b): Polymer bound.

\section{Materials and method}

\section{$2.1 \quad$ Materials}

Polyvinylchloride (PVC), o-nitrophenyloctylether (o-NPOE), methanol, tetrahydrofuran (THF) and graphite were obtained from Fluka (Milwaukee, USA). Glucose oxidase, glutaraldehyde, potassium chloride, glucose, quinhydrone and 1,4-diamino butane were obtained from Merck (Darmstadt, Germany). Epoxy resin was received from Araldite. Polymethylmethacrylate (PMMA), potassium dihydrogen phosphate and acrylic liquid were obtained from Sigma Aldrich (St. Louis, USA). Doubly distilled, deionized water was used for preparing the solutions and throughout the experiments. The supporting electrolyte solutions were $0.05 \mathrm{~mol} / \mathrm{L}$ phosphate buffers ( $\mathrm{pH}$ : 5.0-7.4) and were prepared from $0.1 \mathrm{~mol} / \mathrm{L}$ solutions of phosphoric acid, potassium dihydrogen phosphate, potassium hydrogen phosphate, and potassium hydroxide, adjusted by a $\mathrm{pH}$ meter. Solutions of glucose were freshly prepared as required, in phosphate buffer at the desired $\mathrm{pH}$ and protected from light during investigation. Voltammetric studies were carried out in phosphate buffer solutions, deoxygenated by pure nitrogen. Impedimetric measurements were carried out by high-impedance input galvanostate (Princeton Applied Research, Oak Ridge, USA). A conventional three-electrode cell was used with a glucose biosensor, a saturated $\mathrm{Ag} / \mathrm{AgCl}$ reference electrode (BASi), and a $\mathrm{Pt}$ wire as the counter electrode. Potentiometric measurements were made by a multi-channel potentiometric measurement system that was controlled by a home-made software program.

\subsection{Preparation of glucose biosensor}

A that was coated by hydrogen ion selective membranes. Firstly polyvinylchloride-aminated (PVC- $\mathrm{NH}_{2}$ ) polymer was synthesized. Briefly; 1.43 g PVC, $11.5 \mathrm{~mL}$ 1,4-diaminobutane and $3.5 \mathrm{~mL}$ triethylamine were mixed and refluxed under atmospheric pressure for 3.5 hours. Then the obtained polymer was washed with $\mathrm{HCl}$ and methanol. Subsequently, the impurities were removed by THF and the solution was filtrated and dried. The solid-state $\mathrm{pH}$ layers were prepared by coating one end of a copper wire with quinhydrone-PVC- $\mathrm{NH}_{2}$ and modified graphite material mixed with the epoxy-hardener [14].

The $\mathrm{pH}$ sensitive composite sensor was dried in room temperature for $3 \mathrm{~d}$. Afterwards glucose oxidase was immobilized onto the $\mathrm{pH}$ layer via glutaraldehyde, a bifunctional linker.

\section{Results and discussion}

\subsection{Voltammetric behaviour of the composite glucose biosensor}

This biosensor layer was characterized with three electrode combinations in phosphate buffer solution containing $0.1 \mathrm{~mol} / \mathrm{L} \mathrm{KCl}$ at $\mathrm{pH} 7.2$ including $\mathrm{Fe}(\mathrm{CN}) 6^{3-/ 4-}$ redox couple by using CV and EIS data. CV method was performed under the experimental conditions: scan rate of $50 \mathrm{mV} / \mathrm{s}, 0 \mathrm{~V}$ to $0.5 \mathrm{~V}$ potential range. EIS spectrums were obtained by applying $0.180 \mathrm{mV}$ bias potential between 10000 and $0.05 \mathrm{~Hz}$. The direct oxidation of glucose at the surface of the composite $\mathrm{pH}$ sensor showed no measurable wave in plain supporting electrolyte including in the potential range studied. The biosensor exhibited a remarkable increase in the anodic and cathodic peak currents when the glucose oxidase immobilized onto the composite $\mathrm{pH}$ sensor membrane. When the glucose biosensor is thoroughly rinsed with water and a new voltammogram is recorded in electrolyte solution, the response was retained, and two pairs of anodic and cathodic peaks were observed as reported in literature [16]-[18]. The behavior, which was observed at different concentrations of glucose and several potential scan rates, clearly demonstrates that the electrode functions electrocatalytically toward glucose.

\subsection{Potentiometric Behavior of the Composite Glucose Biosensor}

Glucose oxidase modified composite biosensor experiments on glucose measurements were carried out potentiometrically by two electrode systems. The composite $\mathrm{pH}$ sensitive layer based on the quinhydrone exhibited Nernst response to hydronium ions as seen in Figure 4.

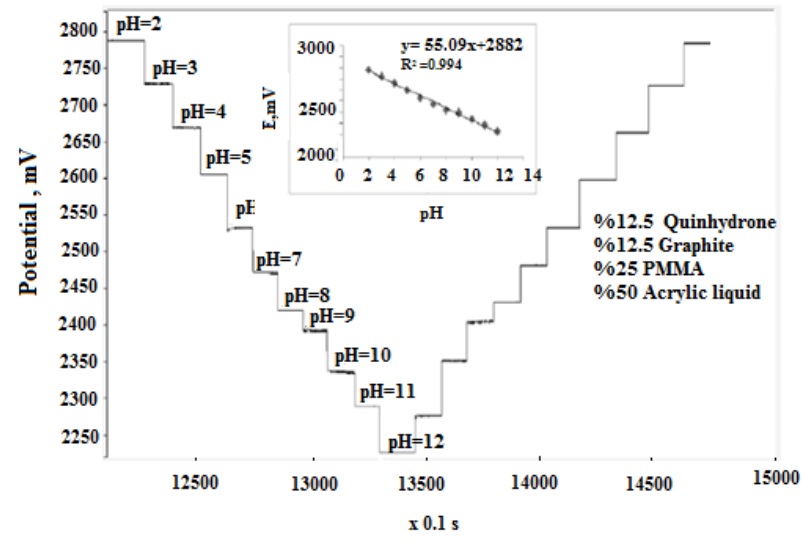

Figure 4: Potentiometric behavior of composite $\mathrm{pH}$ sensor.

For the selectivity coefficient measurements of the composite $\mathrm{pH}$ sensor, $1 \times 10^{-4}-1 \times 10^{-1} \mathrm{~mol} / \mathrm{L}$ solutions of interfering ions were used in buffers at pH 7 and 12. It can be seen from the results that the composite $\mathrm{pH}$ sensor was highly selective for hydronium ions. Selectivity constants of composite $\mathrm{pH}$ sensor against $\mathrm{H}_{3} \mathrm{O}^{+}$ion next to $\mathrm{Na}^{+}, \mathrm{K}^{+}$and $\mathrm{Li}^{+}$ions $\left(-\log \mathrm{k}_{H^{+}, M^{n+}}^{\text {pot }}\right.$ ) were calculated as $5.33,5.63$ and 5.36 at pH 7 buffer and as 11.75 , 10.42 and 11.23 at pH 12 buffer, respectively. The obtained results indicated that the developed composite $\mathrm{pH}$ sensor acts quite selective against hydronium ion in the presence of other ions. 
The repeatability of the composite $\mathrm{pH}$ sensor response was tested with measurements taken randomly in the $\mathrm{pH} 2$ and $\mathrm{pH}$ 12 buffer solutions as shown in Figure 5. The composite $\mathrm{pH}$ sensor exhibited a good repeatability when compared with the results [19]-[22].

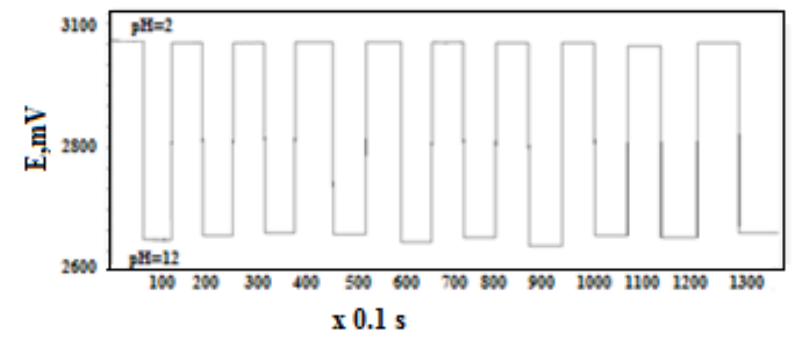

Figure 5: The potential repeatability of the composite $\mathrm{pH}$ sensor.

The slope of the potentiometric glucose biosensor was dependent on the solution $\mathrm{pH}$ and calculated to be between 20$25 \mathrm{mV} /$ decade of glucose concentration indicating an underNernstian response of the glucose biosensor. Maximum sensitivity was observed at $\mathrm{pH} 7.2$ of Tris- $\mathrm{HCl}$ buffer with a slope of $25 \mathrm{mV} /$ decade (Figure 6).

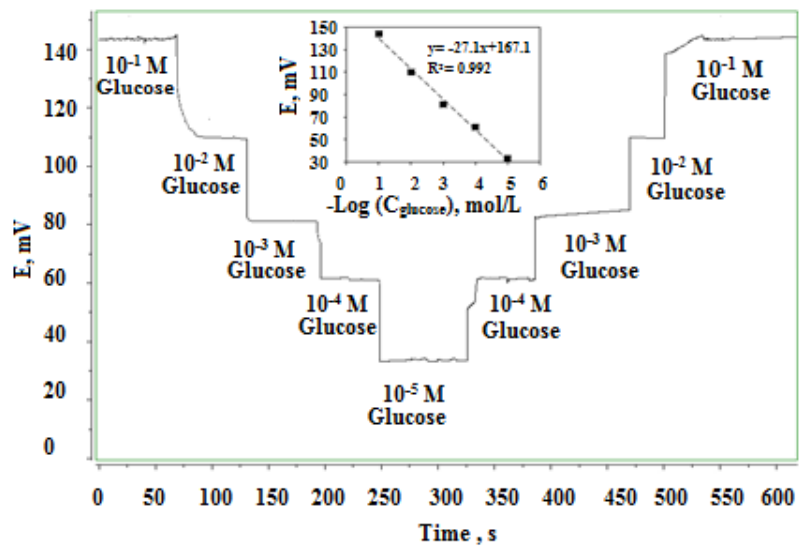

Figure 6: Potentiometric behavior of composite glucose biosensor in Tris-HCl buffer at pH 7.2.

The linear dependence of the glucose concentration has a correlation coefficient of 0.9943 . The composite glucose biosensor exhibited a detection limit of $2 \times 10^{-5} \mathrm{~mol} / \mathrm{L}$, based on three times measurement for the standard deviation of the blank noise. The reproducibility of the potential response of the glucose biosensor was obtained by determining the slope of the calibration graph in a period of one month (n: 5). The biosensor retained its full activity during this period and the slopes of the calibration graphs were reproducible to within $1.5 \mathrm{mV} /$ decade of glucose concentration.

\section{Conclusion}

A new type glucose sensitive potentiometric biosensor by using micro sized composite $\mathrm{pH}$ sensitive sensor is developed. The sensor was characterized by EIS and CV measurements, and it showed excellent potentiometric response with high selectivity. The developed glucose biosensor based on composite $\mathrm{pH}$ sensor has been supposed to give correct, selective and long term repetitive responses to glucose. It is thought that such a sensor can have the potential of measuring glucose continually in a measurement system such as "a glucose watch". Thus, in the next process, the plan is to use the micro sized glucose biosensor to develop "a glucose watch" which can measure the glucose level in blood from the skin without taking blood and through reverse-iontophoresis. In addition, the fact that the glucose biosensor developed here have a longer shelf life, increased heat resistivity and a wider $\mathrm{pH}$ interval that reveals its potential to be used for continuous measurements.

\section{Acknowledgements}

The authors are gratefully acknowledge the financial support provided by Recep Tayyip Erdogan University, Scientific Research Projects Coordinator Unit (BAP) (Project No: RTEU 2015.53008.109.07.01 and the contributions of Prof. Dr. İbrahim IŞILDAK.

\section{References}

[1] Liu Y, Yu T. "Polymers and enzyme biosensors". Journal of Macromolecular Science-Reviews in Macromolecular Chemistry \& Physics, 37( 3), 459-500, 1997.

[2] Ófagain C. "Enzyme stabilization-recent experimental progress". Enzyme and Microbial Technology, 33(2-3) 137-149, 2003.

[3] Ófagain C, Ruzgas T, Gorton L, Csoregi E, Ardila GB, Sakharov IU, Gazaryan, I.G. "Biosensors based on novel peroxidases with improved properties in direct and mediated electron transfer". Biosensors and Bioelectronics, 15(9-10), 491- 497, 2000.

[4] Finfer S, Chittock DR, Su SY, Blair D, Foster D, Dhingra V, Ronco JJ. "Intensive versus conventional glucose control in critically ill patients". The New England Journal of Medicine - Journals, 360(13),1283-1297, 2009.

[5] Wiener R, Wiener D, Larson R. "Benefits and risks of tight glucose control in critically ill adults: a meta-analysis". Journal of the American Medical Association, 300(8), 933- 944, 2008.

[6] Krinsley J, Grover A. "Severe hypoglycemia in critically ill: risk and outcomes". The Journal of Critical Care Medicine, 36(4), 1390-1391, 2008.

[7] Anger K, Szumita P. "Barriers to glucose control in the intensive care unit". Pharmacotherapy, 26(2), 214-228, 2006.

[8] Vriesendorp T, Devries J, Holleman F, Dzoljic M, Hoekstra J. "The use of two continuous glucose sensors during and after surgery". Diabetes Technology and TherapeuticsJournals, 7(2), 315-322, 2005.

[9] Kovatchev B, Anderson S, Heinemann L, Clarke W. "Comparison of the numerical and clinical accuracy of four continuous glucose monitors". Diabetes Care Journal, 31(6), 1160 -1164, 2008.

[10] Koschinsky T, Heinemann L. "Sensors for Glucose monitoring: technical and clinical aspects". Diabetes/Metabolism Research and Reviews, 17(2), 113-123, 2001.

[11] Oliver NS, Toumazou C, Cass AEG, Johnston DG. "Glucose sensors: a review of current and emerging technology". Diabetic Medicine-Journals, 26(3),197-210, 2009.

[12] Lin Y, Lu F, Tu Y, Ren Z. "Glucose biosensors based on carbon nanotube nanoelectrode ensembles". Nano Letters, 4(2), 191-195, 2004.

[13] Lindgren A, Ruzgas T, Gorton L, Csoregi E, Ardila GB, Sakharov IU, Gazaryan IG. "Biosensors based on novel peroxidases with improved properties in direct and mediated electron transfer". Biosensors and Bioelectronics, 15(9-10), 491-497, 2000. 
[14] Tınkılıc N, Cubuk O, Isildak I. "Glucose and urea biosensors based on all solid-state contact PVC-NH2 membrane electrodes". Analytica Chimica Acta, 452(1), 24-29, 2002.

[15] Pörksen JR, Isildak I, Andac M, Yolcu M, Kahlert H, Scholz $\mathrm{F}$, Behnert J. "Application of a new pH-sensitive electrode as a detector in flow injection potentiometry". Electroanalysis, 17(12), 1085-1090, 2005.

[16] Rekha K, Gouda MD, Thakur MS, Karanth NG. "Ascorbate oxidase based amperometric biosensor for organophosphorous pesticide monitoring". Biosensors and Bioelectronic, 15(9-10),499-502, 2000.

[17] Updike SJ, Gilligan BJ, Shults MC, Rhodes RK. "A subcutaneous glucose sensor with improved longevity, dynamic range, and stability of calibration". Diabetes Care, 23(2), 208-214, 2000.

[18] Aussedat B, Thome-Duret V, Reach G, Lemmonier F, Klein JC, Hu L, Wilson GS. "A user-friendly method for calibrating a subcutaneous glucose sensor-based hypoglycemic alarm". Biosensors and Bioelectronics, 12(11), 1061-1071, 1997.
[19] Lenigk R, Lam E, Lai A, Wang H, Han Y, Carlier P, Renneberg R. "Enzyme biosensor for studying therapeutics of Alzheimer's disease". Biosensors and Bioelectronics, 15(9-10), 541-547, 2000.

[20] Ramsay G, Wolpert SM. "Utility of wiring nitrate reductase by alkylpyrroleviologen-based redox polymers for electrochemical biosensor and bioreactor applications". Analytical Chemistry, 71(2), 504-506, 1999.

[21] Bozkurter Cil AT, Bicakci U, Isildak I, Ariturk, E. "pH and antioxidant measurements in rats with testicular torsion and their correlation with viability". Journal of Pediatric Surgery, 51(10), 1716-1720, 2016.

[22] Yolcu, M. Dere, N. "All-Solid-State Potentiometric $\mathrm{Cu}(\mathrm{II})$-Selective Sensor Based on Ion Imprinted Methacrylamide Polymer". Electroanalysis, 30(6), 1-9, 2018. 